\title{
Effects of Confidentiality Perception During Delivery Period on Maternal Satisfaction
}

\section{Doğum Sürecinde Mahremiyet Alglsının Anne Memnuniyetine Etkisi}

\author{
Hatice ORMAN ${ }^{1} \oplus$, Nurdan DEMİRCí ${ }^{2} \odot$ \\ ${ }^{I}$ Taksim Eğitim ve Araştırma Hastanesi, Istanbul, Türkiye \\ ${ }^{2}$ Marmara Üniversitesi, Doğum ve Kadın Hastalıkları Hemşireliği Anabilim Dalı, İstanbul, Türkiye
}

\begin{abstract}
Objective: This cross-sectional descriptive study with integroup comparison has been realized toevaluating the confidentality perception of women who gave birth, during their hospital stay, and determining its effect on their satisfaction

Method: The sample of this study consists of 131 mothers who gave vaginal birth and 94 mothers who had caesarean birth in Istanbul Gaziosmanpasa Taksim Training and Research Hospital's Delivery Room and Obstetrics and Gynecology Clinic. Data were collected using diagnostics form, Bodily Confidentiality Scale for Gynecology and Obstetrics, Scales for Measuring Maternal Satisfaction in Normal and Caesarean Birth, and were analyzed using 22.0 SPSS.

Results: There were not any statistically significant differences between the two groups in terms of the subscale means of Bodily Confidentiality Scale for Gynecology and Obstetrics general confidentiality, rights and confidentiality, ethics and confidentiality, clinical confidentiality. Mean satisfaction scores of mothers who gave vaginal (139.16 \pm 24.50$)$ and cesarean birth (145.65 \pm 24.50$)$ were both below the cut-off level, indicating that despite the $100 \%$ dissatisfaction rate, mothers who gave cesarean birth were more satisfied than the mothers who gave vaginal birth. The most important factor determining the satisfaction level in the vaginal birth group was found to be the dimension of rights and confidentiality. This domain increases the overall level of maternal satisfaction.

Conclusion: The perception of the medical team was observed to have a significant effect on the mothers' confidentiality. Staying in single or double rooms during the labor process has a positive impact on maternal confidentiality and satisfaction.
\end{abstract}

Keywords: Birth process, confidentiality perception, satisfaction, vaginal birth, caesarean birth
ÖZ

\begin{abstract}
Amaç: Doğum yapan annelerin, hastanede bulundukları süre içerisindeki gizlilik algılarının değerlendirilmesi ve memnuniyetlerine etkisini belirlemek amacıyla gruplar arası karşılaştırmalı, kesitsel ve tanımlayıcı olarak yapılmıştır.

Yöntem: Araştırma kapsamında İstanbul Gaziosmanpaşa Taksim Ĕ̈itim ve Araștırma Hastanesi Doğum Odası ve Doğum ve Kadın Hastalıkları Kliniğinde 131 vaginal doğum yapan anne ile 94 sezaryen doğum yapan anne çalışma örneklemini oluşturmuştur. Verilerin toplanmasında tanılama formu, Jinekoloji ve Obstetride Beden Mahremiyeti Ölçeği, Normal Doğum ve Sezaryen Doğumda Anne Memnuniyetini Değerlendirme ölçekleri kullanılmıştır. Veriler 22.0 (SPSS) istatistik paket programı kullanılarak de ğerlendirilmiștir.

Bulgular: Jinekoloji ve Obstetride Beden Gizliliği Ölçeği genel gizlilik, haklar ve gizlilik, etik ve gizlilik, klinik gizlilik alt boyut puan ortalamalart ile vaginal ve sezaryen doğum yapan anneler arasinda istatistiksel olarak anlaml fark bulunmamıştır. Vaginal doğum yapan anneler $(139,16 \pm 24,50)$ ile sezaryen doğum yapan annelerin memnuniyet ortalama puanları $(145,65 \pm 24,50)$ uygulanan ölçeklerin kesme noktast değerinin altında olması nedeniyle \%100'ünün memnun olmadiğı ancak sezaryen doğum yapan annelerin vaginal doğum yapan annelere göre daha memnun olduğu görülmüsstür. Vaginal doğum yapan annelerde memnuniyet düzeyini belirleyen en önemli faktörün haklar ve gizlilik boyutu olduğu bulunmuştur. Haklar ve gizlilik boyutu anne memnuniyeti toplam düzeyini arttırmaktadır.

Sonuç: Sağllk ekibi algılayışının vaginal ve sezaryen doğum yapan annelerin gizliliği üzerinde önemli bir etkiye sahip oldu$\breve{g u}$ görülmüsstür. Travay sürecinde bir-iki kişilik odada kalınması annenin gizliliğini ve memnuniyetini olumlu şekilde etkilemektedir.
\end{abstract}

Anahtar kelimeler: Doğum süreci, gizlilik algısı, memnuniyet, vajinal doğum, sezaryen do ğum 


\section{INTRODUCTION}

The concept of confidentality as a fundamental human right is held true everywhere and, in every area, where people are engaged. Confidentality can be handled with other concepts such as confidentiality, private life, information, religion, private space, sexuality and culture ${ }^{(1)}$.

Hospitals are described as places where patients can not always have control over themselves, so the concept of privacy is violated. Especially during gynecological and obstetric assessment and examination, deprivation of privacy of women causes intense feelings of shame and fear in women. Another situation where privacy needs to be prioritized is labor ${ }^{(2)}$.

During labor, health personnel such as midwife and nurse should observe the privacy of women. Privacy is of paramount importance since it supports health care psychologically. In the sense of privacy, it is reflected through a straightforward and honest communication, and assurance that patient's information will not be disclosed to other people ${ }^{(3)}$.

Privacy can also be referred as a requirement and lifestyle to increase the satisfaction of an individual. It was found that women, who were assisted with midwives having good communication skills and observing the privacy and cultural diversity of women during labor, had better labor experience and higher levels of satisfaction ${ }^{(4)}$.

In the evaluation of patient satisfaction, determining the quality of service provided and the gaps in health care area as well as bridging these gaps are of paramount importance ${ }^{(5)}$. Patient satisfaction is affected by behaving a patient humanely, information sharing, technical competence, overall satisfaction, overall quality, psychosocial problems, sufficiency of financial and physical opportunities, continuity of care and bureaucratic procedures ${ }^{(6)}$.

There are two determinant factors in patient satisfaction: expectation of patients and perception of service they are provided with. Patients have scientific, methodological, and behavioral expectations from health care institutions. These expectations vary with the age, sex, educational background, health services, sociocultural characteristics and previous experiences in health institutions. Perception of service received by patients also varies with patients' characteristic traits and their previous experiences in health institutions ${ }^{(7)}$.

Satisfaction of patients who receive service is one of the most important parameters to evaluate the quality of a health institution and its services. It was reported that the most important factor affecting satisfaction of patients during their stay in hospital was care and services provided by nurses ${ }^{(8)}$.

Cooperation of patient and nurse constitutes a major part of patient satisfaction ${ }^{(9)}$.

In this study, it was aimed to determine the perception of privacy, and its effect on the satisfaction of women who gave birth during their stay in hospital.

\section{METHOD}

\section{Type of the Study}

The study was conducted as a cross-sectional and descriptive study with intergroup comparison.

\section{Location and Characteristics of the Study}

The study was carried out in the Delivery Room and Gynecology and Obstetrics Clinic in the Gaziosmanpaşa Taksim Training and Research Hospital in İstanbul.

\section{Population and Sample of the Study}

The population of the study consisted of mothers who had vaginal and cesarean birth between December 2017 and February 2018 at the Gaziosmanpaşa Taksim Training and Research Hospital. The sample of the study consisted of 131 mothers who had vaginal delivery or gave birth by cesarean section $(n=94)$ within this period, and voluntarily agreed to participate in the study.

\section{Data Collection Tools}

\section{Diagnosis Form}

It consists of 15 questions which were prepared 
according to the literature information, including the sociodemographic characteristics of the participants (age, educational status, occupation, social security, perceived income level), their obstetric characteristics (age at first pregnancy, number of pregnancies, number of live births, gender of the baby), time spent both in the delivery room until delivery, and also in the delivery room during the working hours, the characteristic features of the labor room, and the postpartumroom, the presence of a postpartum companion, and the procedures applied during the delivery process.

\section{Body Privacy Scale for Gynecology and Obstetrics}

The Body Privacy Scale for Gynecology and Obstetrics (BCSGO) was developed by Değirmen et al. especially for our country in 2014. In the overall scale reliability analysis, the Crohnbach's alpha value was $0.840^{(10)}$.

The Body Privacy Scale for Gynecology and Obstetrics consists of 37 questions and 4 subscales as general privacy, rights and privacy, ethics, privacy and clinical privacy.

The scale has not any total score and cut-off point. The total of items constituting each subscale is used as "total subscale score". The perception of privacy is given more importance as the total subscale score of the scale increased.

Five-point 37-item Likert scale was used, with scores ranging from 1 "Strongly Disagree", 2 "Disagree", 3 "Neither Agree or Disagree", 4 "Agree" to 5 "Strongly Agree". The items 21, and 24 of the scale had the highest value with the average score of 4.5966 , and the item 5 had the lowest value with the average score of 3.8115 (Değirmen et al., 2014).

In our study, the Cronbach's alpha reliability coefficients of the scale were found as 0.94 and 0.95 in vaginal birth and cesarean birth, respectively.

\section{Scale for Measuring Maternal Satisfaction in Birth (Vaginal Birth)}

The Scale for Measuring Maternal Satisfaction in Birth (SMMSB) (Vaginal Birth) was developed by
Güngör specially for our country in 2009. It was determined that the Cronbach's Alpha coefficient ranged from 0.67 to 0.89 in the subscales and the total internal consistency of the scale was very high $($ Cronbach's Alpha $=0.91)$.

The Scale for Measuring Maternal Satisfaction in Birth (SMMSB) (Vaginal Birth) consists of 42 questions and 10 subscales; perception of health professionals, nursing care in labor, comforting, information and involvement in decision making, meeting baby, postpartum care, hospital room, hospital facilities, respect for privacy and meeting expectations.

Five-point 43-item Likert scale was used with scores ranging from 1 "Disagree", 2 "Partially Agree", 3 "Neither Agree or Disagree", 4 "Agree" to 5 "Strongly Agree". Thirteen items (7, 8, 9, 10, 19, 20, 21, 22, 35, $36,38,41$, and 42) were reverse scored.

The total of items constituting each subscale is used as "total subscale score". Total raw scores range from 43 to 215 points. As the total score of the scale increases, the level of maternal satisfaction in birth at hospital increases. The calculated cut-off point for the Scale for Measuring Maternal Satisfaction in Vaginal Birth was determined as 150.5 (high satisfaction level $\geq 150.5$, and low satisfaction level $(<150.5)^{(11)}$.

In our study, the Cronbach's Alpha reliability coefficient of the scale was found to be 0.85 .

\section{Scale for Measuring Maternal Satisfaction in Birth. (Cesarean Birth)}

The Scale for Measuring Maternal Satisfaction in Birth (SMMSB) (Cesarean Birth) was developed by GÜNGÖR specially for our country in 2009. It was determined that the Cronbach's Alpha coefficient ranged from 0.65 to 0.88 in the subscales, and the total internal consistency of the scale was very high $($ Cronbach Alpha $=0.91)$.

The Scale for Measuring Maternal Satisfaction in Birth (SMMSB) (Vaginal Birth) consists of 42 questions and 10 subscales; perception of health professionals, preparation for cesarean, comforting, information and involvement in decision making, meeting 
baby, postpartum care, hospital room, hospital facilities, respect for privacy and meeting expectations.

Five -point 42-item Likert scale was used with scores ranging from 1 "Disagree", 2 "Partially Agree", 3 "Neither Agree or Disagree", 4 "Agree" to 5 "Strongly Agree". Twelve items (8, 9, 10, 19, 20, 21, 22, 34, 35, 37,40 , and 41) were reverse scored.

Total raw score ranged from 42 to 210 . As the total score of the scale increased, the level of maternal satisfaction in cesarean birth at hospital increased. The calculated cut-off point for the Scale for Measuring Maternal Satisfaction in Cesarean Birth was determined as 146.5 (high satisfaction level $\geq 146.5$, and low satisfaction level $<146.5)^{(11)}$.

In our study, the Cronbach's Alpha reliability coefficient of the scale was found to be 0.89 .

\section{Statistical Analysis of the Data}

The data obtained in the study were analyzed by using SPSS (Statistical Package for Social Sciences) software for Windows 22.0 Descriptive statistical parametres were used in the evaluation of the data. The relationship between group variables was assessed using a chi-square analysis. T-test was used to compare quantitative continuous data between two independent groups and one-way ANOVA test was used to compare quantitative continuous data among more than two independent groups. The Scheffe test was used as a complementary post-hoc analysis to determine the differences after application of the ANOVA test. Pearson correlation and regression analysis were applied for the continuous variables of the study.

\section{Ethical Aspects of the Study}

Necessary permissions were obtained from the institution in which the study was conducted, and also from the related Public Hospitals Department and scale owners. Ethical approval for this study was obtained from the Ethics Committee of Health Sciences Institute of Marmara University (dated 11.06. 2017 and decision no. 196). The volunteers were informed about the purpose of the study and their verbal and written consents were obtained.

\section{RESULTS}

There was no statistically significant difference between the vaginal and the cesarean birth groups ( $p>0.05$ ) in terms of age, educational status, occupation and social security while a statistically significant difference was found in perceived income level $(\mathrm{p}<0.05$, Table 1$)$.

A statistically significant difference was found between the vaginal and the cesarean birth groups as for time spent until giving birth in delivery room and time spent in delivery room within working hours $(\mathrm{p}<0.05$, Table 2$)$.

Table 1. Distribution of the Women Who Gave Birth by Sociodemographic Features.

\begin{tabular}{|c|c|c|c|c|c|c|c|c|}
\hline \multirow{2}{*}{\multicolumn{2}{|c|}{ Sociodemographic Features }} & \multicolumn{2}{|c|}{ Vaginal Birth } & \multicolumn{2}{|c|}{ Cesarean Birth } & \multicolumn{2}{|c|}{ Total } & \multirow[b]{2}{*}{$\mathrm{X}^{2}$ and $\mathrm{p}$ Value } \\
\hline & & $\mathbf{n}$ & $\%$ & $\mathbf{n}$ & $\%$ & $\mathbf{n}$ & $\%$ & \\
\hline \multirow{4}{*}{ Age } & 18-25 Years Old & 57 & 43.5 & 30 & 31.9 & 87 & 37.7 & \multirow{4}{*}{$\begin{array}{c}\mathrm{X}^{2}=3.502 \\
\mathrm{p}=0.321\end{array}$} \\
\hline & 26-30 Years Old & 35 & 26.7 & 32 & 34.1 & 67 & 30.4 & \\
\hline & 31-35 Years Old & 22 & 16.8 & 16 & 17 & 38 & 16.9 & \\
\hline & Above 36 Years Old & 17 & 13 & 16 & 17 & 33 & 15 & \\
\hline \multirow[t]{2}{*}{ Educational Status } & Primary School and Lower & 84 & 64.1 & 54 & 57.4 & 138 & 60.8 & \multirow{2}{*}{$\begin{array}{l}\mathrm{X}^{2}=1.028 \\
\mathrm{p}=0.191\end{array}$} \\
\hline & High School and College & 47 & 35.9 & 40 & 42.6 & 87 & 39.2 & \\
\hline \multirow[t]{2}{*}{ Occupation } & Housewife & 107 & 81.7 & 72 & 76.6 & 179 & 79.1 & \multirow{2}{*}{$\begin{array}{l}\mathrm{X}^{2}=0.870 \\
\mathrm{p}=0.222\end{array}$} \\
\hline & Working & 24 & 18.3 & 22 & 23.4 & 46 & 20.9 & \\
\hline \multirow[t]{2}{*}{ Social Security } & Yes & 98 & 74.8 & 73 & 77.7 & 171 & 76.2 & \multirow{2}{*}{$\begin{array}{l}\mathrm{X}^{2}=0.244 \\
\mathrm{p}=0.370\end{array}$} \\
\hline & No & 33 & 25.2 & 21 & 22.3 & 54 & 23.8 & \\
\hline \multirow[t]{3}{*}{ Perceived Income Level } & Sufficient & 19 & 14.5 & 27 & 28.7 & 46 & 21.6 & \multirow{3}{*}{$\begin{array}{l}\mathrm{X}^{2}=7.042 \\
\mathrm{p}=0.030\end{array}$} \\
\hline & Middle & 78 & 59.5 & 49 & 52.1 & 127 & 55.8 & \\
\hline & Insufficient & 34 & 26 & 18 & 19.2 & 52 & 22.6 & \\
\hline
\end{tabular}


A statistically significant difference was not found between the mothers of the vaginal and the cesarean birth groups in terms of average scores of general privacy, rights and privacy, ethics and privacy, clinical privacy subscales ( $p>0.05$, Table 3$)$.

A statistically significant difference was found between the average scores of BPSGO subscales of the women who gave birth and the labor room property variable, and between the average scores for general privacy and for ethics and privacy scores $(\mathrm{p}<0.05$, Table 4).

The average satisfaction scores of the women who gave vaginal or cesarean birth were found to be $139.16 \pm 24.50$ and $145.65 \pm 24.50$, respectively. The cut-off points determined for SMMSB (vaginal birth) and SMMSB (cesarean birth) were 150.5 and 146.5, respectively. Since the average maternal satisfaction scores were below the cut-off value, a $100 \%$ decrease was found in the satisfaction level (Table 5).

Table 5. Average Satisfaction Scores of SMMSB.

\begin{tabular}{lccccc}
\hline & N & Avg. & Ss & Min. & Max. \\
\hline SMMSB (Vaginal) & 131 & 139.16 & 24.5 & 72 & 215 \\
SMMSB (Cesarean) & 94 & 145.65 & 20.54 & 94 & 187
\end{tabular}

Table 2. Distribution of the Women Who Gave Birth by Birth Process Properties.

\begin{tabular}{|c|c|c|c|c|c|c|c|c|}
\hline \multirow[b]{2}{*}{ Birth Process Properties } & & \multicolumn{2}{|c|}{ Vaginal Birth } & \multicolumn{2}{|c|}{ Cesarean Birth } & \multicolumn{2}{|c|}{ Total } & \multirow[b]{2}{*}{$\mathrm{X}^{2}$ and $\mathrm{p}$ Value } \\
\hline & & $\mathbf{n}$ & $\%$ & $\mathbf{n}$ & $\%$ & $\mathbf{n}$ & $\%$ & \\
\hline $\begin{array}{l}\text { Time Spent until Giving } \\
\text { Birth in Delivery Room }\end{array}$ & $\begin{array}{l}2 \text { hours and below } \\
3-4 \text { hours } \\
5 \text { hours and above }\end{array}$ & $\begin{array}{l}36 \\
22 \\
73\end{array}$ & $\begin{array}{l}27.5 \\
16.8 \\
55.7\end{array}$ & $\begin{array}{l}38 \\
24 \\
32\end{array}$ & $\begin{array}{c}40.5 \\
25.5 \\
34\end{array}$ & $\begin{array}{c}74 \\
46 \\
105\end{array}$ & $\begin{array}{c}34 \\
21.2 \\
44.8\end{array}$ & $\begin{aligned} \mathrm{X}^{2} & =10.346 \\
\mathrm{p} & =0.006\end{aligned}$ \\
\hline $\begin{array}{l}\text { Time Spent in Delivery } \\
\text { Room within Working Hours }\end{array}$ & $\begin{array}{l}2 \text { hours and below } \\
3-4 \text { hours } \\
5 \text { hours and above }\end{array}$ & $\begin{array}{l}44 \\
44 \\
43\end{array}$ & $\begin{array}{l}33.6 \\
33.6 \\
32.8\end{array}$ & $\begin{array}{l}51 \\
21 \\
22\end{array}$ & $\begin{array}{l}54.3 \\
22.3 \\
23.4\end{array}$ & $\begin{array}{l}95 \\
65 \\
65\end{array}$ & $\begin{array}{l}44 \\
28 \\
28\end{array}$ & $\begin{array}{c}\mathrm{X}^{2}=9.614 \\
\mathrm{p}=0.008\end{array}$ \\
\hline
\end{tabular}

Table 3. Comparison of Average Scores of BPSGO Sub-scales by Mode of Birth.

\begin{tabular}{|c|c|c|c|c|c|c|}
\hline BCSGO Sub-scales & Group & $\mathbf{n}$ & Avg. & Ss & $\mathbf{t}$ & p value \\
\hline \multirow[t]{2}{*}{ General Privacy } & Vaginal Birth & 131 & 4.062 & 0.739 & \multirow[t]{2}{*}{0.122} & \multirow[t]{2}{*}{0.903} \\
\hline & Cesarean Birth & 94 & 4.05 & 0.748 & & \\
\hline \multirow[t]{2}{*}{ Rights and Privacy } & Vaginal Birth & 131 & 4.295 & 0.724 & \multirow[t]{2}{*}{0.075} & \multirow[t]{2}{*}{0.94} \\
\hline & Cesarean Birth & 94 & 4.287 & 0.734 & & \\
\hline \multirow[t]{2}{*}{ Ethics and Privacy } & Vaginal Birth & 131 & 4.205 & 0.704 & \multirow[t]{2}{*}{0.429} & \multirow[t]{2}{*}{0.668} \\
\hline & Cesarean Birth & 94 & 4.164 & 0.7 & & \\
\hline \multirow[t]{2}{*}{ Clinical Privacy } & Vaginal Birth & 131 & 4.505 & 0.585 & \multirow[t]{2}{*}{-0.033} & \multirow[t]{2}{*}{0.974} \\
\hline & Cesarean Birth & 94 & 4.508 & 0.568 & & \\
\hline
\end{tabular}

Table 4. Comparison of the Birth Process Properties of the Women who Gave Birth by Average Scores of BPSGO Sub-scales.

\begin{tabular}{|c|c|c|c|c|c|c|}
\hline Birth Process Properties & & $\mathbf{n}$ & General Privacy & Rights and Privacy & Ethics and Privacy & Clinical Privacy \\
\hline \multirow{7}{*}{ Vaginal Birth } & Properties of Labor Room & & Avg. \pm SD & Avg.. SD & Avg. \pm SD & Avg. \pm SD \\
\hline & Single Room & 25 & $4.253 \pm 0.461$ & $4.304 \pm 0.583$ & $4.432 \pm 0.442$ & $4.520 \pm 0.342$ \\
\hline & Double Room & 49 & $4.179 \pm 0.647$ & $4.457 \pm 0.523$ & $4.290 \pm 0.567$ & $4.588 \pm 0.429$ \\
\hline & Triple Room & 57 & $3.877 \pm 0.869$ & $4.151 \pm 0.891$ & $4.032 \pm 0.855$ & $4.427 \pm 0.757$ \\
\hline & $\mathrm{F}=$ & & 3.354 & 2.41 & 3.515 & 1.016 \\
\hline & $\mathrm{p}=$ & & 0.038 & 0.094 & 0.033 & 0.365 \\
\hline & PostHoc $=$ & & $1>3,2>3(\mathrm{p}<0.05)$ & & $1>3(\mathrm{p}<0.05)$ & \\
\hline \multirow{7}{*}{ Cesarean Birth } & Properties of Labor Room & & Avg...SD & Avg. \pm SD & Avg. \pm SD & Avg... SD \\
\hline & Single Room & 18 & $3.778 \pm 0.953$ & $4.011 \pm 1.132$ & $3.789 \pm 0.998$ & $4.299 \pm 0.929$ \\
\hline & Double Room & 26 & $3.872 \pm 0.621$ & $4.408 \pm 0.608$ & $4.223 \pm 0.569$ & $4.513 \pm 0.405$ \\
\hline & Triple Room & 50 & $4.240 \pm 0.686$ & $4.324 \pm 0.594$ & $4.268 \pm 0.596$ & $4.580 \pm 0.457$ \\
\hline & $\mathrm{F}=$ & & 3.748 & 1.712 & 3.393 & 1.636 \\
\hline & $p=$ & & 0.027 & 0.186 & 0.038 & 0.2 \\
\hline & PostHoc $=$ & & $3>1,3>2(p<0.05)$ & & $2>1,3>1(p<0.05)$ & \\
\hline
\end{tabular}


Table 6. Effect of Total Score of SMMSB Maternal Satisfaction Sub-scales in the Women who Gave Birth on the BPSGO Sub-scales.

\begin{tabular}{|c|c|c|c|c|c|c|c|c|}
\hline & Dependent Variable & Independent Variable & B & $\mathbf{t}$ & $\mathbf{p}$ & $\mathbf{F}$ & Model (p) & $\mathbf{R}^{2}$ \\
\hline & Total Maternal Satisfaction & Constant & 102.834 & 6.204 & 0 & & & \\
\hline & & General Privacy & 2.494 & 0.586 & 0.559 & & & \\
\hline \multirow[t]{5}{*}{ Vaginal Birth } & & Rights and Privacy & 9.843 & 2.055 & 0.042 & 2.488 & 0.047 & 0.044 \\
\hline & & Ethics and Privacy & -2.568 & -0.458 & 0.648 & & & \\
\hline & & Clinical Privacy & -1.172 & -0.206 & 0.837 & & & \\
\hline & Total Maternal Satisfaction & Constant & 112.914 & 6.589 & 0 & & & \\
\hline & & General Privacy & 0.518 & 0.134 & 0.894 & 1.593 & 0.183 & 0.025 \\
\hline \multirow[t]{3}{*}{ Cesarean Birth } & & Rights and Privacy & -5.648 & -1.239 & 0.219 & & & \\
\hline & & Ethics and Privacy & 7.51 & 1.495 & 0.138 & & & \\
\hline & & Clinical Privacy & 5.231 & 1.033 & 0.304 & & & \\
\hline
\end{tabular}

In the women who gave vaginal birth, the regression analysis between the total scores of SMMSB maternal satisfaction, and the BPSGO subscales was found to be statistically significant $(\mathrm{p}=0,047<0.05)$. General privacy, rights and privacy, ethics and privacy, clinical privacy accounted for $4.4 \%$ of total change in the total maternal satisfaction level $(\mathrm{R} 2=0.044)$. Improvement in Rights and Privacy variable increased the total maternal satisfaction level $(\beta=9.843)$.

In the women who gave cesarean birth, the regression analysis was not found to be statistically significant as for the above-mentioned parametres $(\mathrm{F}=1.593$; $\mathrm{p}=0.183>0.05$, Table 6 ).

\section{DISCUSSION}

The effect of income level on fertility is complicated. It varies according to the level of development of countries, the socio-economical group being included, the definition, scope of income, and way of earning one's living, ${ }^{(12)}$. In our study, a statistically significant difference in perceived income level was found between the groups $(p<0.05$, Table 1$)$. While the middle-income level findings showed parallelism with the study by Çapık et al. ${ }^{(13)}$, while the findings between the groups did not show any parallelism. The differences between the groups could be affected by the determination of cesarean indications and the fact that the study was conducted in different geographical regions, and the increased trend towards cesarean birth among high-income women in Western regions of Turkey.

Giving birth is a laborious but unforgettable process in a woman's life. Upon the start of labor process, the mother is taken to delivery room and monitored. Within this period, necessary preparations for the birth are completed, the likelihood of various risks are evaluated and the mode of birth (cesarean or vaginal) is decided ${ }^{(13)}$. In our study, it was found that $27.5 \%$ of the women who gave vaginal and $40.5 \%$ of the women who gave cesarean birth spent 2 hours or less in the delivery room until birth. In our study, a statistically significant intergroup difference was found in terms of time spent in the delivery room $(\mathrm{p}<0.05$, Table 2).

Shorter times in delivery room and within working hours in cesarean births can be interpreted to be associated with repeated cesarean births and shorter preparation period for emergency and cesarean birth. Increased number of employees within working hours allows to manage challenging situations more quickly. Vaginal Birth should be monitored since it lasts longer than cesarean birth and hence prolonged stay in delivery room is anticipated.

Privacy is a fundamental human right which can vary with several factors such as individual self, culture, and lifestyle etc. Privacy of patients should be respected in all health practices. Birth process is also a practice that should be paid attention in this respect. During delivery, exposure of intimate body parts makes the women feel ashamed. Protection of women's privacy plays an important role on their levels of satisfaction ${ }^{(14,15)}$. In our study, a statistically significant difference was not found between the vaginal and the cesarean birth groups in terms of average score of BPSGO subscales including general privacy, rights and privacy, ethics and privacy and clinical privacy ( $>0.05$, Table 3 ). In the study by Aslan and Okumuş ${ }^{(16)}$ on 450 primipar women, no relationship between the mode of birth and the privacy expectation levels was found. In the study performed by Bekmezci et al. ${ }^{(15)}$ to evaluate the percei- 
ved privacy during labor on 230 women who gave birth, it was found that the mothers perceived privacy during labor at a high level. The results of our study showed parallelism with the studies by Aslan and Okumuş ${ }^{(16)}$ and Bekmezci et al. ${ }^{(15)}$.

It was determined that privacy perception did not vary by mode of birth between the vaginal and the cesarean birth groups.

In our study, it was found that privacy perception was affected by the characteristic features of labor room. In an exploratory and qualitative study performed by Arslan and Demir ${ }^{(17)}$ on 10 participants working in a public hospital in İzmir, it was found that the women completed birth process in single private rooms, and stayed in single rooms until they were discharged which was extremely important in terms of privacy. In the qualitative phenomenological study by Sayın (14) on a group consisting of 8 pregnant women, 12 women who gave birth and 15 health professionals, it was stated that giving birth in a single room was important. In the study by Sayın ${ }^{(14)}$, a 29 -year-old, primary school graduate woman who gave birth stated: "I think, single room is required for the mother, and her attendant to make them feel comfortable." A 27-year-old, undergraduate woman who gave birth stated: "There should be separate rooms because everyone looks at each other, and pass-byers are disruptive". The studies by Arslan and Demir (17) and Sayin ${ }^{(14)}$ support our study data. In our study, it was found that among the women who gave vaginal birth, and those stayed in single and double rooms had higher general privacy perception scores than those stayed in triple rooms, and those stayed in single rooms had higher privacy perception scores than those stayed in triple rooms. In our study, it was found that among the women who gave cesarean birth, those stayed in triple rooms had higher general privacy perception scores than those stayed in single and double rooms, and those stayed in double and triple rooms had higher privacy perception scores than those stayed in single rooms. Those stayed in single rooms among the women who gave vaginal birth and those stayed in triple rooms among the women who gave cesarean birth had higher awareness in terms of privacy perception and evaluation. During the period when the mothers had undergone examinations and operations in the labor room, exposure of their inti- mate parts and the likelihood of being seen by other women made them feel ashamed. It can be said that those stayed in single rooms were more advantageous than those stayed in triple rooms in terms of protection of their privacy.

Patient satisfaction is a concept that covers many aspects such as the provision of the service, the interaction between the patient and the service providers, the existence and continuity of the service, the adequacy of the service providers and the communication between them. Meeting the expectations of patients ensures their satisfaction with the service provided. Patient satisfaction usually appears as an indicator of the quality of care in the provision of healthcare services. Maternal satisfaction is an important indicator for evaluating the birth experience ${ }^{(18-21)}$. In our study, the average satisfaction scores of the women who gave vaginal or cesarean birth were found as $139.16 \pm 24.50$ and $145.65 \pm 24.50$, respectively. Since the average maternal satisfaction scores were below the cut-off point, the satisfaction level was found to decrease $100 \%$ (Table 5). In the studies by Çapık et al. ${ }^{(13)}$ and Çıtak Bilgin et al. ${ }^{(21)}$, it was found that the women who gave vaginal birth were more satisfied with the mode of birth. Our study did not show parallelism with the studies by Çapık et al. ${ }^{(13)}$ and Çıtak Bilgin and et al. (21). In our study, it was suggested that the satisfaction level was affected by other factors than mode of birth. Based on our findings, since the average maternal satisfaction levels of the women who gave vaginal or cesarean birth were below the cut-off points of the applied scale, it was found that $100 \%$ of the mothers were not satisfied, however, the women who gave cesarean birth were more satisfied than the women who gave vaginal birth.

It was determined that the most important factor determining the level of satisfaction in the women who gave vaginal birth was the rights and privacy subscale of the SMMSB. The Rights and Privacy subscale of the SMMSB increased the total maternal satisfaction level. It was concluded that paying attention to the rights and privacy subscale could increase the satisfaction level in the women who gave vaginal birth.

\section{CONCLUSIONS and RECOMMENDATIONS}

Protection of women's privacy at birth process is an 
important issue. Thus, personal requests to ensure privacy perception should be considered and the privacy should be ensured in nursing process. Since respecting the privacy increases maternal satisfaction, the health care team should show sensitivity to this issue as required. Labor rooms and postpartum rooms should be designed as single rooms to meet the requirements. Hospital facilities should meet the requirements of the mothers, attendants and visitors. Necessary arrangements in the waiting room should be made. Traffic through the delivery room and postpartum room should be arranged. Necessary measures should be taken to protect privacy in all interventions performed on the mothers and necessary information should be always provided before any operation. The mother's expectations should be considered and necessary arrangements should be made accordingly. The women who will give birth should be provided training on the rights and privacy during pregnancy and before birth.

Ethics Committee Approval: T.C. Approval of the Ethics Committee of Marmara University Institute of Health Sciences was obtained (2017/196).

Conflict of Interest: There is no conflict of interest between the authors.

Funding: No funding was used in this study.

Informed Consent: After giving information about the study, written consent was obtained.

Etik Kurul Onayı: T.C. Marmara Üniversitesi Sağlık Bilimleri Enstitüsü Etik Kurulu onayı alınmıştır (2017/196).

Çıkar Çatışması: Yazarlar arasında çıkar çatışması yoktur.

Finansal Destek: Bu çalışmada hiçbir fon kullanılmamıştır.

Hasta Onamı: Çalışma ile ilgili bilgilendirme yapıldıktan sonra yazılı onam alınmıştır.

\section{REFERENCES}

1. Akyüz EB. Ameliyat Olan Hastalarda Hemşirelik Bakım Uygulamalarının Mahremiyete/ Kişisel Gizliliğe Etkileri Konusunda Hastaların ve Hemşirelerin Görüşleri. B.Ü. Sağlık Bilimleri Enstitüsü, Yüksek Lisans Tezi, 2008.

2. Bekmezci H, Özkan H. Ebelik uygulamalarında mahremiyetin önemi. Sağ Bil Mesl Dergisi. 2015;2(1):113-24. [CrossRef]
3. Mobach MP. Counter design influences the privacy of patients in health care. Soc Sci Medicine. 2009;68:1000-5. [CrossRef]

4. Aktaş S, Pasinlioğlu T. Ebenin empatik iletişim becerisinin doğum eylemine ve doğum sonrası döneme etkisi. A Hemş Sağ Bil Dergisi. 2016;19:38-45.

5. Arpacı F, Aksoy AD. Sağlık hizmeti pazarlamasında tüketici memnuniyeti: Yaşlıların hastane hizmetlerine ilişkin görüssleri. Vocational Edu. 2011;6(4):120-9.

6. Akbaş E. Sağlik hizmetlerinde hasta memnuniyeti ve hasta memnuniyetini etkileyen faktörler (Manisa Merkezefendi devlet hastanesi örneği). B. Ü. Sosyal Bilimler Enstitüsü, Yüksek Lisans Tezi. 2014.

7. Yazgan M. Sağlık işletmelerinde hizmet kalitesinin sağlik hizmeti sunan ve sağlık hizmeti alan taraflarca değerlendirilmesi, D. E. Ü. Sağlık Bilimleri Ensitüsü, Yüksek Lisans Tezi. 2009.

8. Bilgin Y, Göral M. Sağlık kuruluşlarında hizmet kalitesinin hasta memnuniyetine etkisi: bartın devlet hastanesi örneği. Bartın Üni İ̈BFD. 2017;8(16):151-76.

9. Zaim H, Tarım M. Hasta memnuniyeti: Kamu hastaneleri üzerine bir alan araştırması. Sosyal Siyaset Konf Dergisi. 2010;(59):1-24.

10. Değirmen N. Jinekoloji ve obstetride beden mahremiyeti: Kütahya örneği. O. Ü. Sağlık Bilimleri Enstitüsü, Doktora Tezi. 2014.

11. Güngör İ. Doğumda anne memnuniyetini değerlendirme ölçeğinin geliştirilmesi. İ.Ü. Sağlık Bilimleri Enstitüsü, Doktora Tezi. 2009.

12. Akça H, Ela M. Türkiye'de Eğitim, Doğurganlık ve İşsizlik İlişkisinin Analizi. Maliye Dergisi. 2012;163:22342 .

13. Çapık A, Sakar T, Yıldırım N, Karabacak K, Korkut M. Annelerin doğum şekline göre memnuniyet durumlarının belirlenmesi.Anadolu Hemşirelik ve Sağlık Bilimleri Dergisi. 2016;19(2):92-9. [CrossRef]

14. Sayın DS. Perinatal hizmetlerde mahremiyet alg1S1. Marmara Üniversitesi Sağlık Bilimleri Enstitüsü Yüksek Lisans Tezi. 2013.

15. Bekmezci H, Özkan H, Koç Ö. Annelerin doğum eyleminde algıladıkları mahremiyetin değerlendirmesi. Turkiye Klinikleri J Health Sci. 2016;1(2):104-10. [CrossRef]

16. Aslan Ş, Okumuş F. Primipar Kadınların Doğum Deneyim Algıları Üzerine Doğum Beklentilerinin Etkisi. HSP. 2017;4(1):32-40. [CrossRef]

17. Arslan E T, Demir, H. Sağlık çalışanlarının hasta mahremiyetine ilişkin tutumu: Nitel bir araştırma. Abant İzzet Baysal Üni Sos Bil Enst Dergisi. 2017;4:191-220. 
18. Kaya A. Sezeryan doğum sonu serviste yatan annelerin aldıkları hemşirelik bakımı ile ilgili memnuniyet düzeylerinin belirlenmesi. Selçuk Üniversitesi, Sağlık Bilimleri Enstitüsü, Yüksek Lisans Tezi. 2011.

19. Aksakal T, Bilgili N. Hemşirelik hizmetlerinde memnuniyetin değerlendirilmesi; Jinekoloji servisi Örneği.Erciyes T1p Dergisi. 2008;30(4):242-9.
20. Arslan Gürcüoğlu E, Vural G. Annelerin doğum sonu dönemde hastanede verilen ebelik/hemşirelik bakımından memnuniyetleri. Gazi Medical Journal. 2018;29(1):34-40. [CrossRef]

21. Çıtak Bilgin N, Ak B, Coşkuner Potur D, Ayhan F. Doğum yapan kadınların doğumdan memnuniyeti ve etkileyen faktörler. Sağlık Bilimleri ve Meslekleri Dergisi. 2018;5:342-52. [CrossRef] 